\title{
MENINGKATKAN KUALITAS PENDIDIKAN MELALUI KEBIJAKAN MANAJEMEN BERBASIS SEKOLAH DAN TANTANGANNYA
}

\author{
Yuyun Elizabeth Patras, Agus Iqbal' ${ }^{1}$ Papat $^{2}$, Yulia Rahman ${ }^{3}$ \\ ${ }^{1}$ Pascasarjana Universitas Pakuan \\ ${ }^{2}$ Guru Bahasa Arab MTs. Assalam, ${ }^{2}$ Kepala SDN Kopo 03, \\ ${ }^{3}$ Guru Matematika MTs. Al-Mu'awwanah \\ Korespondensi: kuuipo21ramadhan@gmail.com
}

\begin{abstract}
The purpose of this study is to describe the policy of School Based Management (SBM) and the challenges of improving the quality of education. The method used in this study is the study of literature. The result of this study is that SBM is a decentralized strategy to take educational decisions by involving parents, students, teachers, officials, and the community to achieve autonomy, participation, participation, independence, responsibility, and school accountability. SBM indicators success are the approval of the principal, teacher, sufficient financial resources, clear commitment, responsibility, skills and qualifications of school officials, appropriate plans, responsibilities, and accountability. The successful implementation of SBM requires socialization, openness, motivation, and unification of vision.
\end{abstract}

Keywords: School Based Management, Indicators, quality of education

\begin{abstract}
ABSTRAK
Tujuan penelitian ini adalah untuk mendeskripsikan kebijakan Manajemen Berbasis Sekolah (MBS) dan tantangan untuk meningkatkan kualitas pendidikan. Metode yang digunakan pada penelitian ini adalah kajian literatur. Hasil dari kajian ini yaitu MBS adalah suatu strategi desentralisasi pengambilan keputusan pendidikan dengan melibatkan orang tua, siswa, guru, pejabat, dan masyarakat untuk mencapai otonomi, fleksibilitas, partisipasi, kemandirian, tanggung jawab, dan akuntabilitas sekolah. Indikator keberhasilan MBS yaitu meliputi dukungan kepala sekolah, guru, sumber keuangan yang cukup, komitmen yang jelas, tanggung jawab, keterampilan dan kualifikasi pejabat sekolah, rencana yang tepat, tanggung jawab, dan akuntabilitas. Keberhasilan implementasi MBS memerlukan adanya sosialisasi, keterbukaan, motivasi, dan penyatuan visi.
\end{abstract}

Kata Kunci: Manajemen Berbasis Sekolah, Indikator keberhasilan, Kualitas Pendidikan

\section{PENDAHULUAN}

Pendidikan yang baik tidak hanya melibatkan input fisik seperti ruang kelas, guru dan buku teks tetapi pada pengajaran dan pembelajaran yang lebih baik. Menurut Purcell dan Ahlstrand (Kiragu, King'oina, \& Migosi, 2013), dalam banyak sistem pendidikan, muncul pengakuan bahwa pengambilan keputusan dan manajemen berbasis sekolah berpotensi 
membawa peningkatan kualitas pendidikan. Bertolak dari latar belakang inilah semakin banyak minat dalam desentralisasi layanan pendidikan termasuk fungsi manajemen sumber daya manusia. Malen et al.(Kiragu et al., 2013), berpendapat bahwa MBS dapat dilihat secara konseptual sebagai perubahan formal dari struktur pemerintahan, sebagai bentuk desentralisasi yang mengidentifikasi sekolah individu sebagai unit utama perbaikan dan bergantung pada redistribusi otoritas pengambilan keputusan sebagai sarana utama yang melaluinya perbaikan mungkin dirangsang dan dipertahankan. Dengan demikian dalam MBS tanggung jawab dan wewenang pengambilan keputusan atas operasi sekolah dialihkan ke kepala sekolah, guru, orang tua dan kadang-kadang ke siswa dan anggota komunitas sekolah lainnya. Namun, para aktor di tingkat sekolah ini harus mematuhi atau beroperasi dalam serangkaian kebijakan yang ditentukan oleh pemerintah pusat. Program MBS ada dalam berbagai bentuk, baik dalam hal siapa yang memiliki kekuatan untuk membuat keputusan dan dalam hal tingkat pengambilan keputusan yang dilimpahkan ke tingkat sekolah.

Menurut PH Slamet (Hamid, 2018) MBS perlu diterapkan karena di lapangan ditemukan kenyataan-kenyataan sebagai berikut: 1) Manajemen berbasis pusat memiliki banyak kelemahan, 2) Sekolah paling memahami permasalahannya, 3) Perubahan akan terjadi jika semua warga sekolah berpartisipasi dalam merencanakan dan merumuskan kebijakan sekolah, 4) Telah lama pengaturan yang bersifat birokratik lebih dominan daripada tanggungjawab profesional.

Berdasarkan fakta di atas, kajian mengenai Manajemen Berbasis Sekolah (MBS) atau School Based Management (SBM) sangat diperlukan.

SBM mengacu pada peningkatan keterlibatan orang tua, siswa, guru, pejabat, kepala sekolah dan kelompok penerima manfaat dari masyarakat dan organisasi lokal dapat meningkatkan kemandirian, tanggung jawab, dan akuntabilitas sekolah (Saeid Moradi, Hussin, \& Barzegar, 2013)

Menurut World Bank (Aslam, 2013) Manajemen berbasis sekolah (MBS) dianggap sebagai strategi desentralisasi pengambilan keputusan pendidikan dengan meningkatkan keterlibatan orang tua dan masyarakat di sekolah. Odden, \& Busch (Aslam, 2013) menegaskan bahwa tidak diragukan lagi, sistem MBS lebih berhasil ketika sekolah menggunakan otoritas pengambilan keputusan mereka untuk merekrut dan memilih staf yang mendukung dan setuju dengan visi sekolah. Jelas bahwa sistem MBS telah menciptakan peluang bagi administrasi sekolah untuk mencapai otonomi, fleksibilitas, partisipasi, dan akuntabilitas.

Manajemen berbasis sekolah adalah desentralisasi sistematis ke tingkat otoritas dan tanggung jawab sekolah untuk membuat keputusan tentang hal-hal penting terkait dengan operasi sekolah dalam kerangka tujuan, kebijakan, kurikulum, standar, dan akuntabilitas yang ditentukan secara terpusat (Caldwell, 2005).

Oswald menjelaskan bahwa MBS adalah strategi untuk mereformasi sistem pendidikan melalui transfer otoritas keputusan dari kantor pendidikan umum ke sekolah. Dengan kata lain, MBS didefinisikan sebagai desentralisasi otoritas keputusan dan memindahkannya ke sekolah (Saeed Moradi, Aminbidohkti, Barzegar, Hussin, \& Branch, 2013)

Berdasarkan beberapa pengertian mengenai MBS oleh beberapa ahli di atas, penulis mensistesiskan bahwa MBS adalah suatu strategi desentralisasi pengambilan keputusan 
pendidikan dengan melibatkan orang tua, siswa, guru, pejabat, dan masyarakat untuk mencapai otonomi, fleksibilitas, partisipasi, kemandirian, tanggung jawab, dan akuntabilitas sekolah.

Sagala (Ihsan; Djailani; AR; Sakdiah Ibrahim, 2014) menjelaskan bahwa mutu pendidikan adalah gambaran dan karakteristik menyeluruh jasa pelayanan pendidikan secara internal maupun eksternal yang kemampuannya memuaskan kebutuhan yang diharapkan atau yang tersirat mencakup input, proses, dan output pendidikan.

Kualitas pendidikan mengacu pada karakteristik yang diinginkan dari peserta didik (siswa yang sehat dan termotivasi), proses (guru yang kompeten menggunakan pedagogi aktif), konten (kurikulum yang relevan) dan sistem (tata kelola yang baik dan alokasi sumber daya yang adil) (UNESCO, 2005).

Menurut UNICEF, kualitas pendidikan mencakup lima dimensi kualitas: peserta didik, lingkungan, konten, proses dan hasil. Ada sejumlah persyaratan untuk mencapai kualitas pendidikan: siswa harus memiliki kesehatan dan gizi yang baik; guru harus terlatih dengan baik dan teknik pembelajaran harus baru; fasilitas dan materi pembelajaran harus memadai; kurikulum harus relevan dan tergantung pada keterampilan, pengetahuan, dan pengalaman para guru dan siswa; lingkungan harus sehat dan aman untuk mendorong pembelajaran. Selain itu, dukungan keluarga untuk belajar sangat signifikan dan penilaian hasil pembelajaran harus didefinisikan secara akurat. Dalam pendidikan, tingkat kualitas yang tinggi berarti tingkat prestasi akademik yang tinggi di antara individu. Menurut Heyneman and Loxley, kualitas pendidikan merupakan input penting dari prestasi sekolah (Biltagy, 2013).

Dari beberapa definisi di atas, penulis mensintesiskan kualitas pendidikan merupakan karakteristik menyeluruh jasa pelayanan pendidikan yang meliputi lima dimensi kualitas yaitu peserta didik yang sehat dan termotivasi, lingkungan yang sehat dan aman, kurikulum yang relevan (konten), guru menggunakan pedagogi aktif serta tata kelola yang baik (proses), dan hasil pembelajaran secara akurat.

\section{METODE RISET}

Kajian mengenai Manajemen Berbasis Sekolah (MBS) dilakukan melalui kajian literatur. Kajian literatur yaitu kegiatan mencari informasi dengan cara mengumpulkan berbagai sumber tertulis yang relevan dengan obyek yang akan dibahas, mencari referensi teori yang relevan dengan kasus atau permasalahan yang ditemukan. Referensi ini dapat dicari dari buku, jurnal, artikel laporan penelitian, dan situs-situs di internet. Berdasarkan kajian literatur tersebut, penulis memaparkan rumusan masalah pada penelitian ini, yaitu: 1) Apakah yang dimaksud Manajemen Berbasis Sekolah (MBS) dan karakteristiknya?, 2) Apa saja indikator keberhasilan MBS?, dan 3) Apakah tantangan pelaksanaan MBS di sekolah?

\section{HASIL DAN PEMBAHASAN}

\section{A. Konsep Manajemen Berbasis Sekolah (MBS) dan karakteristiknya}

Dalam pasal 51 Undang-Undang RI Nomor 20 tahun 2003 tentang Sistem Pendidikan Nasional dijelaskan bahwa pengelolaan satuan pendidikan anak usia dini, pendidikan dasar, dan pendidikan menengah dilaksanakan berdasarkan standar pelayanan minimal dengan prinsip manajemen berbasis sekolah/madrasah. 
Sejalan dengan pemberlakuan undang-undang otonomi daerah, maka Depdiknas telah melakukan penyesuaian-penyesuaian terhadap pendekatan manajemen pendidikan yaitu dari manajemen berbasis pusat menuju manajemen berbasis sekolah, seperti yang tercantum pada tabel berikut:

\begin{tabular}{|c|c|c|}
\hline Manajemen Berbasis Pusat & Menuju & Manajemen Berbasis Sekolah \\
\hline p-ordinasi & & pnomi \\
\hline Pengambilan keputusan & & Pengambilan keputusan \\
\hline pusat & & tisipatif \\
\hline Ruang gerak kaku & & Ruang gerak luwes \\
\hline idekatan birokratik & & Pendekatan profesionalisme \\
\hline \begin{tabular}{|l} 
Sentralistik Diatur \\
\end{tabular} & & Desentralistik \\
\hline erregulasi & & regulasi \\
\hline ngontrol & & mpengaruhi \\
\hline ngarahkan & & Memfasilitasi \\
\hline nghindari resiko & & ngolah resiko \\
\hline nakan uang semuanya & & Gunakan uang seefisien mungkin \\
\hline Individual cerdas & & amwork kompak \& cerdas \\
\hline ormasi terpribadi & & prmasi terbagi \\
\hline Pendelegasian & & nberdayaan \\
\hline ganisasi hierarkis & & ganisasi datar \\
\hline
\end{tabular}

(Sumber: PH Slamet (Hamid, 2018))

Manajemen berbasis sekolah memiliki karakteristik yang perlu dipahami oleh sekolah yang akan menerapkannya. Dengan kata lain, jika sekolah ingin berhasil dalam menerapkan MBS, maka beberapa karakteristik MBS perlu dipelajari dan dipahami dengan baik. Membahas karakteristik MBS tidak dapat dipisahkan dengan karakteristik sekolah efektif. Jika MBS dianggap sebagai wadah/kerangkanya maka sekolah efektif merupakan isinya. Oleh sebab itu, karkteristik MBS memuat elemen-elemen sekolah efektif yang dikategorikan menjadi input, proses dan output (Hamid, 2018).

Input pendidikan adalah segala sesuatu yang harus tersedia karena dibutuhkan untuk berlangsungnya suatu proses. Sesuatu yang dimaksud berupa sumber daya dan perangkat lunak serta harapan-harapan sebagai pemandu berlangsungnya proses. Input sumberdaya meliputi sumberdaya manusia (kepala sekolah, guru, konselor, karyawan, peserta didik) dan sumberdaya selebihnya (peralatan, perlengkapan, uang, bahan,dsb) (Hamid, 2018).

Proses merupakan berubahnya "sesuatu" menjadi "sesuatu yang lain". Sesuatu yang berpengaruh terhadap berlangsungnya proses disebut input, sedangkan sesuatu dari hasil proses disebut output. Pada penyelenggaraan pendidikan di sekolah-sekolah, yang dimaksud dengan proses pendidikan meliputi empat hal yaitu: 1) Proses pengambilan keputusan. 2) Proses pengelolaan kelembagaan. 3) Proses pengelolaan program. 4) Proses belajar mengajar. Output pendidikan adalah prestasi sekolah yang dihasilkan oleh proses pembelajaran dan manajemen. Output sekolah dapat diukur dengan kinerja sekolah yang terdiri dari: (1) Efeketifitas; (2) Kualitas; (3) Produktivitas; (4) Efisiensi; (5) Inovasi; (6) Kualitas kehidupan kerja; dan (7) Moral kerja. 
Gambaran mengenai otonomi manajemen sekolah dan desentralisasi fungsi manajemen sekolah adalah sebagai berikut:

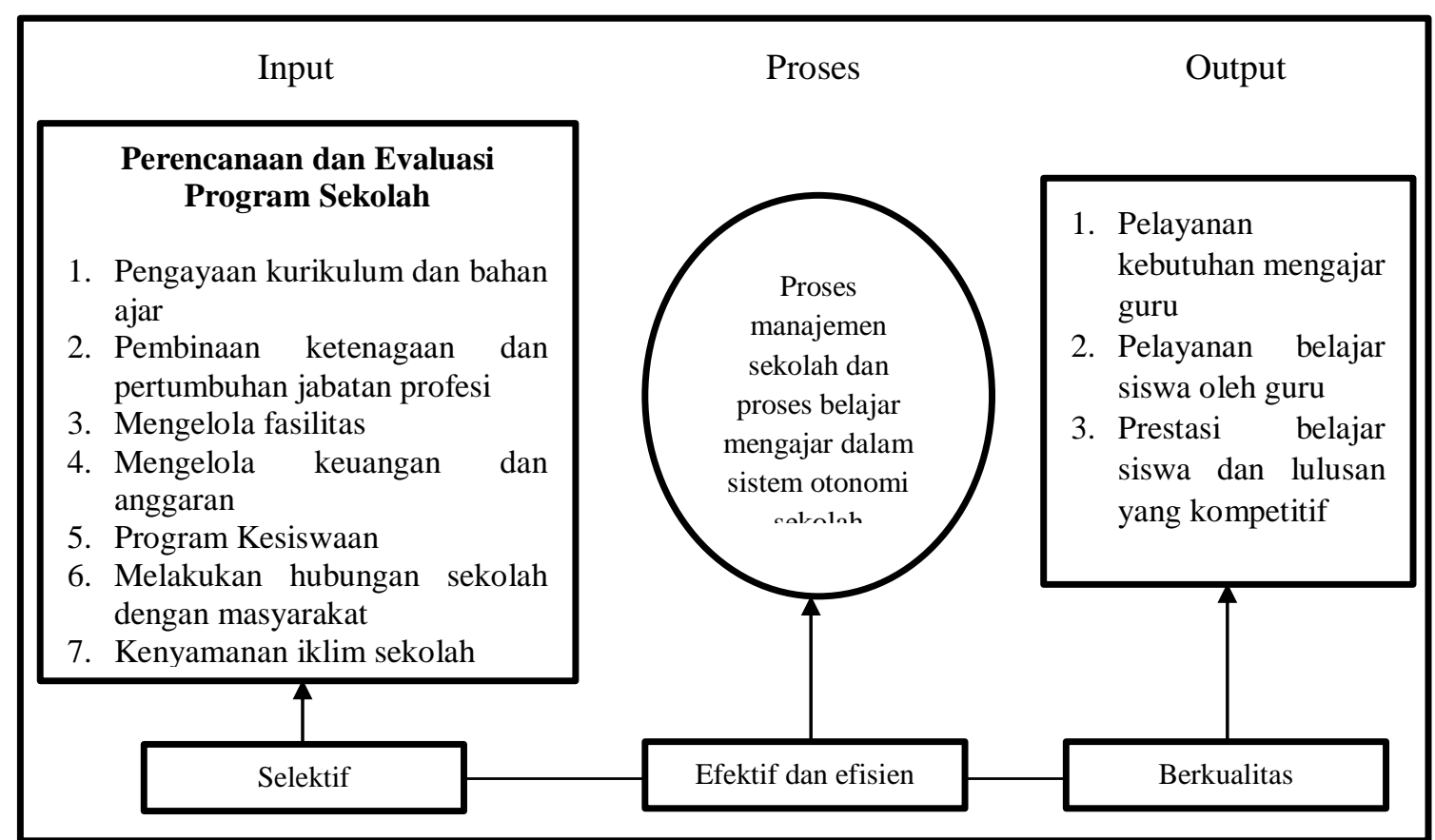

Sumber: Sagala, 2010

\section{B. Indikator Keberhasilan MBS}

Kualitas sekolah tidak hanya ditentukan oleh nilai akhir sekolah, tetapi ada faktor lain seperti: bagaimana kegiatan belajar mengajar dilaksanakan, bagaimana kompetensi guru dan tenaga kependidikan di sekolah tersebut ditingkatkan, bagaimana fasilitas dna perlengkapan pembelajaran disediakan sekolah, termasuk apakah sekolah dapat melaksanakan kegiatan ekstrakurikuler dengan baik [12].

Suhardan (Suprihatin, 2017) mengemukakan indikator keberhasilan Manajemen Berbasis Sekolah (MBS), yaitu meliputi:

1. Efektivitas proses pembelajaran;

2. Kepemimpinan sekolah yang kuat;

3. Pengelolaan tenaga yang efektif;

4. Kepemilikan budaya mutu sekolah;

5. Sekolah memiliki team work yang kompak, cerdas, dan dinamis;

6. Sekolah memiliki kemandirian;

7. Partisipasi warga sekolah dan masyarakat;

8. Transparansi sekolah;

9. Sekolah memiliki kemampuan untuk mengubah dalam psikis dan fisik;

10. Responsif dan antisipatif terhadap kebutuhan.

Manajemen berbasis sekolah dianggap sebagai faktor untuk meningkatkan efektivitas dan efisiensi pendidikan di tingkat sekolah. Beberapa intelektual percaya bahwa faktor penting 
untuk kemakmuran sekolah dalam reformasi MBS meliputi dukungan kepala sekolah, guru, sumber keuangan yang cukup, komitmen yang jelas, tanggung jawab, keterampilan dan kualifikasi pejabat sekolah, rencana yang tepat, tanggung jawab, dan akuntabilitas. Terlepas dari beragam sudut pandang, para pengambil keputusan sistem pendidikan harus menghadapi masalah dalam memilih sudut pandang yang tepat. Sementara itu prasyarat untuk keberhasilan implementasi konsep ini di sekolah adalah partisipasi, kerja sama, tanggung jawab dan pertanggungjawaban orang-orang ini terhadap rencana bantuan (Saeid Moradi et al., 2013).

Oswald (Pratiwi, 2016) berpendapat agar MBS berjalan sukses perlu memperhatikan beberapa strategi yaitu: (a) kepala sekolah harus menggunakan pendekatan kelompok untuk mengambil keputusan, (b) guru-guru harus lebih bersikap positip terhadap kepemimpinan sekolah dan lebih melibatkan diri pada tujuan dan sasaran sekolah, (c) orang tua dan anggota masyarakat harus menjadi penyokong sekolah, sebab mereka memiliki lebih pemikiran dalam keputusan

\section{Tantangan Pelaksanaan MBS di sekolah}

Hasil penelitian UNESCO dalam Mustuningsih mengungkapkan bahwa masalah implementasi MBS di Indonesia dapat dikelompokkan menjadi 4, yaitu:

1. Manajemen sekolah,

2. Peran serta masyarakat,

3. Kegiatan belajar mengajar dan

4. Out put.

Ditinjau dari manajemen sekolah, problematika MBS antara lain sekolah belum banyak melibatkan semua pihak atau pihak luar dalam mengambil keputusan. Kesadaran guru terhadap budaya kedisiplinan dan tanggungjawabnya dalam melaksanakan tugas yang diberikan. Oleh karena itu, sosialisasi, keterbukaan, motivasi, dam penyatuan visi sangat mempengaruhi keberhasilan implementasi MBS. (Batubara \& Arian, 2017)

Adapun faktor lain dari masalah penerapan MBS menurut Jenni dalam Mustuningsih adalah:

1) Kurangnya kemampuan dan pengalaman sekolah untuk mengadopsi dan menerima perubahan,

2) Inovasi MBS dibangun tanpa ada perencanaan yang jelas dan jadwal yang pasti,

3) Kurang aplikatifnya desain model MBS,

4) Jalur birokrasi/komunikasi yang terlalu panjang terkadang tidak memberikan pemahaman yang jelas tentang MBS,

5) Kurang banyaknya pelatihan/ penataran terkait dengan penerapan MBS atau hasil-hasil pelatihan tidak diterapkan di sekolah sehingga sumber daya manusia di SD belum semuanya memahami langkah-langkah dan prinsip-prinsip MBS. (Batubara \& Arian, 2017)

Menurut Arcana et. Al. (Arcana, Dantes, \& Marhaeni, 2015) Sejak digulirkannya model pengelolaan Manajemen Berbasis Sekolah (MBS) tahun 2005 sekolah- sekolah dalam mengimplementasikannya masih banyak mengalami hambatan atau masalah, seperti banyak tenaga kependidikan dan tenaga pendidik yang belum memahami substansi dari pengelolaan 
sekolah dengan menggunakan model Manajemen Berbasis Sekolah (MBS). Hal ini dikarenakan belum tersosialisasikannya secara benar tentang konsep MBS itu sendiri. Pemahaman personel baik tenaga pendidik maupun tenaga kependidikan pemahamannya terhadap keberadaan MBS masih setengah-setengah. Dan bahkan dalam pelaksanaannya masih banyak yang menyimpang dari konsep yang sebenarnya.

Menurut Wibowo (Wibowo \& Yogyakarta, n.d.) berdasarkan hasil wawancara dengan beberapa informan diketahui kendala-kendala yang dihadapi oleh sekolah ini dalam pelaksanaan MBS, antara lain adalah:

1. Dana.

2. Tenaga kependidikan kurang.

3. Kadang-kadang terjadi perbedaan pendapat di antara guru meskipun tidak sampai berpengaruh kepada siswa.

4. Sarana dan prasarana khususnya peralatan sudah mulai usang.

5. Ada beberapa guru yang sudah sepuh umurnya tidak mau tahu dengan kemajuan teknologi

\section{KESIMPULAN}

Berdasarkan pembahasan, penulis menyimpulkan hal-hal sebagai berikut:

1. Manajemen Berbasis Sekolah (MBS) adalah suatu strategi desentralisasi pengambilan keputusan pendidikan dengan melibatkan orang tua, siswa, guru, pejabat, dan masyarakat untuk mencapai otonomi, fleksibilitas, partisipasi, kemandirian, tanggung jawab, dan akuntabilitas sekolah.

2. Indikator keberhasilan MBS meliputi dukungan kepala sekolah, guru, sumber keuangan yang cukup, komitmen yang jelas, tanggung jawab, keterampilan dan kualifikasi pejabat sekolah, rencana yang tepat, tanggung jawab, dan akuntabilitas.

3. Keberhasilan implementasi MBS terkendala oleh beberapa faktor antara lain: sekolah belum banyak melibatkan semua pihak atau pihak luar dalam mengambil keputusan, kesadaran guru terhadap budaya kedisiplinan dan tanggung jawabnya dalam melaksanakan tugas yang diberikan. Oleh karena itu perlu adanya sosialisasi, keterbukaan, motivasi, dam penyatuan visi.

\section{DAFTAR PUSTAKA}

Arcana, I. N., Dantes, N., \& Marhaeni, A. A. I. N. (2015). STUDI EVALUATIF TENTANG KUALITAS PELAKSANAAN MANAJEMEN BERBASIS SEKOLAH DI SD GUGUS INTI KECAMATAN ABANG, 5, 1-12.

Aslam, H. D. (2013). School-Based Management in Oman: Principalsâ€ TM Views and Understanding. International Journal of Academic Research in Progressive Education and Development, 2(3), 84-96. https://doi.org/10.6007/ijarped/v2-i3/2

Batubara, H. H., \& Arian, D. N. (2017). IMPLEMENTASI MANAJEMEN BERBASIS SEKOLAH DI SDN SUNGAI MIAI 5 DAN SDN SURGI MUFTI 4 DI BANJARMASIN, 3, 452-461.

Biltagy, M. (2013). Quality of Education, Earnings and Demand Function for Schooling in Egypt: An Economic Analysis. Procedia - Social and Behavioral Sciences, 69(Iceepsy 
2012), 1741-1750. https://doi.org/10.1016/j.sbspro.2012.12.123

Caldwell, B. J. (2005). Management. Paris: The International Institute for Educational Planning (IIEP).

Hamid, H. (2018). Manajemen Berbasis Sekolah. Al-Khwarizmi: Jurnal Pendidikan Matematika Dan Ilmu Pengetahuan Alam, 1(1), 87-96. https://doi.org/10.24256/jpmipa.v1i1.86

Ihsan; Djailani; AR; Sakdiah Ibrahim. (2014). Penerapan Manajemen Berbasis Sekolah dalam Meningkatkan Mutu Pendidikan di SD Negeri 62 Kota Banda Aceh. Jurnal Administrasi Pendidikan Pascasarjana Universitas Syiah Kuala, 4(2), 12-20.

Kiragu, J. W., King'oina, J. O., \& Migosi, J. A. (2013). School-based management prospects and challenges: A case of public secondary schools in murang'a south district. International Journal of Asian Social Science, 3(5), 1166-1179. Retrieved from http://www.aessweb.com/journal-detail.php?id=5007

Moradi, Saeed, Aminbidohkti, A. A., Barzegar, N., Hussin, S. Bin, \& Branch, I. (2013). The Implementation of School-Based Management Concept in Tehran, 3(4), 442-446.

Moradi, Saeid, Hussin, S. Bin, \& Barzegar, N. (2013). School-Based Management (SBM), Opportunity or Threat (Education systems of Iran). Procedia - Social and Behavioral Sciences, 69(Iceepsy), 2143-2150. https://doi.org/10.1016/j.sbspro.2012.12.179

Pratiwi, S. N. (2016). Manajemen Berbasis Sekolah Dalam Meningkatkan Kualitas Sekolah. Jurnal EduTech Maret, 2(1), 2442-6024.

Suprihatin, B. (2017). Meningkatkan Profesionalisme Guru Melalui Implementasi Manajemen Berbasis Sekolah ( Mbs ) Di Sd Sahara Kabupaten Bandung, 11(2), 89-98.

UNESCO. (2005). Chapter 1: Understanding education quality. EFA Global Monitoring Report 2005, 27-37.

Wibowo, U. B., \& Yogyakarta, U. N. (n.d.). Implementasi Manajemen Berbasis Sekolah (MBS) - Sukarti, Udik Budi Wibowo 269, 1, 269-284. 